\title{
Chinese Cinnamon Leaf Oil
}

National Cancer Institute

\section{Source}

National Cancer Institute. Chinese Cinnamon Leaf Oil. NCI Thesaurus. Code C107287.

The essential oil of Cinnamomum cassia. Cinnamon leaf oil is used primarily in aromatherapy. 